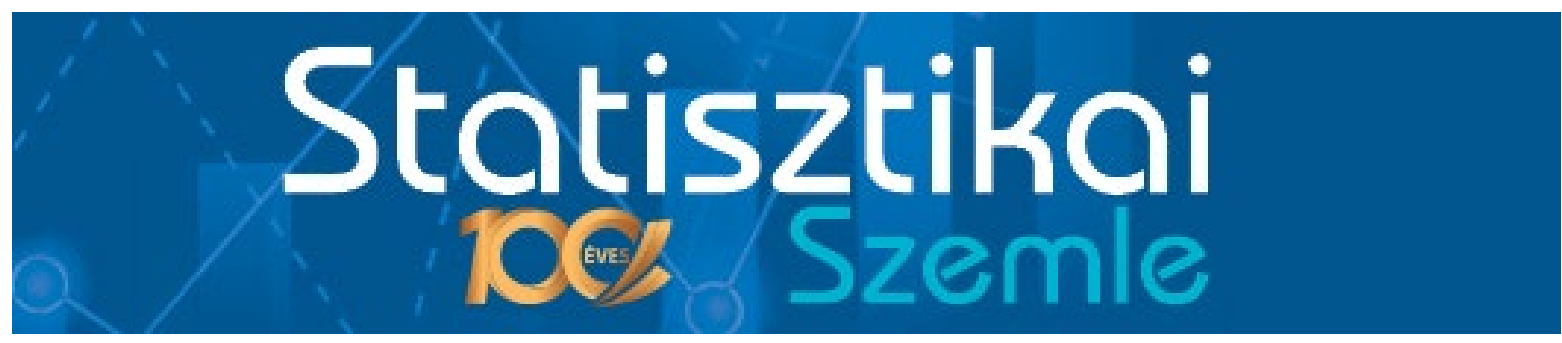

Közzététel: 2022. január 14.

A tanulmány címe:

Pálinkavásárlási preferenciák vizsgálata a magyar fogyasztók körében egy diszkrét választási modell építése

\title{
Szerzők:
}

MARó ZALÁN MÁRK,

a Budapesti Corvinus Egyetem PhD-hallgatója

E-mail: zalan.maro@uni-corvinus.hu

TöröK ÁrON,

a Budapesti Corvinus Egyetem tanszékvezető egyetemi docense

E-mail: aron.torok@uni-corvinus.hu

\section{BALOGH PÉTER,}

a Debreceni Egyetem intézetigazgató egyetemi tanára

E-mail: balogh.peter@econ.unideb.hu

\section{CZINe Péter,}

a Debreceni Egyetem tanársegédje

E-mail: czine.peter@econ.unideb.hu

DOI: https://doi.org/10.20311/stat2022.1.hu0044

Az alábbi feltételek érvényesek minden, a Központi Statisztikai Hivatal (a továbbiakban: KSH) Statisztikai Szemle c. folyóiratában (a továbbiakban: Folyóirat) megjelenő tanulmányra. Felhasználó a tanulmány vagy annak részei felhasználásával egyidejüleg tudomásul veszi a jelen dokumentumban foglalt felhasználási feltételeket, és azokat magára nézve kötelezőnek fogadja el. Tudomásul veszi, hogy a jelen feltételek megszegéséből eredő valamennyi kárért felelősséggel tartozik.

1. A jogszabályi tartalom kivételével a tanulmányok a szerzői jogról szóló 1999. évi LXXVI. törvény (Szjt.) szerint szerzői münek minősülnek. A szerzői jog jogosultja a KSH.

2. A KSH földrajzi és időbeli korlátozás nélküli, nem kizárólagos, nem átadható, térítésmentes felhasználási jogot biztosít a Felhasználó részére a tanulmány vonatkozásában.

3. A felhasználási jog keretében a Felhasználó jogosult a tanulmány:

a) oktatási és kutatási célú felhasználására (nyilvánosságra hozatalára és továbbítására a 4. pontban foglalt kivétellel) a Folyóirat és a szerző(k) feltüntetésével;

b) tartalmáról összefoglaló készítésére az írott és az elektronikus médiában a Folyóirat és a szerző(k) feltüntetésével;

c) részletének idézésére - az átvevő mü jellege és célja által indokolt terjedelemben és az eredetihez híven - a forrás, valamint az ott megjelölt szerző(k) megnevezésével.

4. A Felhasználó nem jogosult a tanulmány továbbértékesítésére, haszonszerzési célú felhasználására. Ez a korlátozás nem érinti a tanulmány felhasználásával előállított, de az Szjt. szerint önálló szerzői münek minősülő mü ilyen célú felhasználását.

5. A tanulmány átdolgozása, újra publikálása tilos.

6. A 3. a)-c.) pontban foglaltak alapján a Folyóiratot és a szerző(ke)t az alábbiak szerint kell feltüntetni:

„Forrás: Statisztikai Szemle c. folyóirat 100. évfolyam 1. számában megjelent, Maró Zalán Márk, Török Aron, Balogh Péter, Czine Péter által írt, 'Pálinkavásárlási preferenciák vizsgálata a magyar fogyasztók körében - egy diszkrét választási modell építése' címü tanulmány (link csatolása)"

7. A Folyóiratban megjelenő tanulmányok kutatói véleményeket tükröznek, amelyek nem esnek szükségképpen egybe a KSH vagy a szerzők által képviselt intézmények hivatalos álláspontjával. 
Maró Zalán Márk - Török Áron - Balogh Péter - Czine Péter

\title{
Pálinkavásárlási preferenciák vizsgálata a magyar fogyasztók körében - egy diszkrét választási modell építése*
}

\section{Examining pálinka (palinka) purchasing preferences among Hungarian consumers - discrete choice modelling}

\author{
MARÓ ZALÁN MÁRK, \\ a Budapesti Corvinus Egyetem \\ PhD-hallgatója \\ E-mail: zalan.maro@uni-corvinus.hu \\ TÖRÖK ÁRON, \\ a Budapesti Corvinus Egyetem \\ tanszékvezetö egyetemi docense \\ E-mail: aron.torok@uni-corvinus.hu
}

\author{
BALOGH PÉTER, \\ a Debreceni Egyetem intézetigazgató \\ egyetemi tanára \\ E-mail: balogh.peter@econ.unideb.hu \\ CZINE PÉTER, \\ a Debreceni Egyetem tanársegédje \\ E-mail: czine.peter@econ.unideb.hu
}

A szerzők egy olyan diszkrét választási kísérlet részleteit ismertetik, amely a pálinkafogyasztók preferenciáit vizsgálta. A pálinka Magyarország nemzeti, az Európai Unió által elismert itala, amelynek minősége és fogyasztása jelentős változáson ment keresztül az elmúlt évtizedekben. A tanulmány célja nemcsak a kísérlet eredményeinek bemutatása, de annak ismertetése is, hogy miként célszerü felépíteni egy több szempontból (statisztikailag és az adott szakterület vonatkozásában) is megalapozott diszkrét választási modellt. A górcső alá vont termékattribútumok között a földrajzi jelzés, a márka, a (kisüsti) főzési mód és az ár szerepel. A felmérés válaszadói mintája 760 föből, többségükben közép- vagy felsőfokú végzettséggel rendelkező férfiakból áll, mivel a szakirodalom és a gyakorlati tapasztalatok alapján e nem képviselői fogyasztanak jellemzően pálinkát Magyarországon. A szerzők multinomiális logit modellbecslések segítségével megállapítják, hogy a Gönci fölrajzi jelzés, a Bestillo márkajelzés és a kisüsti főzési mód növelik a vásárlók hasznosságérzetét. A modellilleszkedési mutatók alapján, illetve a szakma szempontjából is megfelelö-

* A tanulmány a Budapesti Corvinus Egyetem Vállalkozásfejlesztési Intézetének, az EFOP 3.6.3-VEKOP16-2017-00007 „»Tehetségből fiatal kutató« - A kutatói életpályát támogató tevékenységek a felsőoktatásban” című projekt, valamint az Innovációs és Technológiai Minisztérium ÚNKP-21-3-I. kódszámú Új Nemzeti Kiválóság Programjának támogatásával készült. A publikációhoz kapcsolódó kutatások elvégzését és a publikáció elkészítését az NKFIH FK124800 „Az élelmiszer minőségi rendszerek és rövid élelmiszer ellátási láncok gazdasági és társadalmi hatásai Magyarországon” címủ pályázat támogatta.

STATISZTIKAI SZEMLE, 100. ÉVFOLYAM 1. SZÁM 44-67. OLDAL DOI: 10.20311/stat2022.1.hu0044 
nek ítélhető modell becslései rávilágítanak arra, hogy a Bestillo márkajelzéssel rendelkező pálinkát inkább a nagyvárosban élők preferálják.

TÁRGYSZÓ: pálinka, diszkrét választási modellépítés, földrajzi jelzés

This study describes the details of a discrete choice experiment that examined pálinka (palinka) consumer preferences. Pálinka is the national drink in Hungary, recognized by the European Union, which has undergone significant changes in terms of quality and consumption in recent decades. In addition to presenting the results of the experiment, the authors aim to demonstrate how to construct a discrete choice model based on several (statistical and pálinka industrial) aspects. The geographical indication, brand, small-pot (in Hungarian 'kisüst') ${ }^{1}$ production method, and the price are classified as attributes of the experiment. The sample consisted of 760 respondents, mostly men with secondary or higher education, as members of this sex can be considered as typical pálinka consumers in the country, based on the literature and experience. According to the estimation of the multinomial logit models, the Gönc ${ }^{2}$ geographical indication, the Bestillo brand, and the kisüst production method increase the sense of utility of the customers. The results obtained from the best model (which can be considered excellent in terms of its goodness of fit and by the pálinka industry) indicate that metropolitan consumers prefer Bestillo-branded pálinka to nonmetropolitan buyers.

KEYWORD: pálinka, discrete choice model building, geographical indication

A pálinka Magyarország nemzeti kincse és itala, amelynek minősége az elmúlt évtizedekben jelentős változáson ment keresztül. A rendszerváltozástól egészen az ezredforduló környékéig silány minőségű szeszes italnak tekintették (Török [2013]), hiszen háromféle italt is ezzel az elnevezéssel illettek: 1. a finomszeszből különböző aromák felhasználásával készült termékeket (például az ízesített vodkát); 2. a finomszesz, aroma és valódi gyümölcspálinka keverékeit (az ún. „vágott" tételeket); valamint 3. a ténylegesen csak gyümölcsből készült alkoholos italokat és párlatokat (Harcsa [2018]). 2002-ben lépett hatályba a Magyar Élelmiszerkönyv (Codex Alimentarius Hungaricus) 1-3-1576 számú rendelkezése (Magyar Élelmiszerkönyv Bizottság [2002]), amely a pálinka egyediségéröl szóló, több évtizedes vita végére tett pontot. Ennek értelmében csak a 100 százalékban gyümölcsböl készült, legalább 37,5 százalék alkoholfokos italok tekinthetők és nevezhetők pálinkának. Szintén a pálinka rangjának helyreállítását szolgálja a 2008-ban elfogadott LXXIII. törvény (az ún. „pálinkatörvény”; Magyar Közlöny [2008]), amely a pálinka

\footnotetext{
${ }^{1}$ Double-distilled palinka made in a copper pot not exceeding a volume of 1,000 litres.

${ }^{2}$ Gönc is a district in north-eastern part of Borsod-Abaúj-Zemplén County in Hungary.
}

STATISZTIKAI SZEMLE, 100. ÉVFOLYAM 1. SZÁM 44-67. OLDAL DOI: 10.20311/stat2022.1.hu0044 
és a törkölypálinka előállítását, minősítését és ellenőrzését szabályozza, valamint rendelkezik a Pálinka Nemzeti Tanács megalapításáról is. Ez a jogszabály - összhangban a 110/2008/EK európai parlamenti és tanácsi rendelettel (Európai Unió Hivatalos Lapja [2008]) - azokat a gyümölcspárlatokat nevezi pálinkának, amelyek Magyarországon termesztett gyümölcsböl készülnek, és cefrézésüket, lepárlásukat, érlelésüket, palackozásukat is hazánkban végzik. Továbbá megszabja a fölrajzi jelzős oltalomra jogosult pálinkák tekintetében azokat a szigorúbb egyedi termékleírásokat, amelyeknek az általános törvényi leírás mellett még e gyümölcspárlatoknak meg kell felelniük. Jelenleg a következö tíz, Magyarország valamely régiójából vagy helységéböl származó pálinka rendelkezik EU-s (európai uniós) földrajzi jelzés oltalommal: Békési szilvapálinka, Kecskeméti barackpálinka, Szabolcsi almapálinka, Szatmári szilvapálinka (valamennyi 2003 óta), Gönci barackpálinka (2008 óta), Újfehértói meggypálinka (2013 óta), Nagykunsági birspálinka, Nagykunsági szilvapálinka, Madarasi birspálinka, valamint Vasi vadkörte pálinka (valamennyi 2021 óta) (Európai Bizottság [2021]).

A földrajzi árujelzős oltalmon túl a pálinka a Hungarikum Bizottság döntése értelmében 2013 márciusa óta minősül hungarikum terméknek. A magyar nemzeti értékekről és hungarikumokról szóló 2012. évi XXX. törvény (Magyar Közlöny [2012]) alapján a hungarikumok nem feltétlenül kötődnek egy adott földrajzi területhez, viszont egyedi és megőrzendő értéknek tekintendők, amelyek a magyar egységet, öntudatot és összetartozást reprezentálják. Fontos kiemelni a jövedéki adóról szóló 2016. évi LXVIII. törvényt (Magyar Közlöny [2016]) is; ennek értelmében Magyarországon három módon készülhet gyümölcsböl alkoholos ital (párlat vagy pálinka). Magánfözés esetében valaki otthon, saját gyümölcsből, a saját tulajdonában álló desztilláló berendezéssel készíti el az alkoholos italt. Bérfőzetésről akkor beszélhetünk, ha valaki egy bérfőzést végző szeszfözde szolgáltatásait veszi igénybe. Kereskedelmi célú előállítás során pedig egy vállalkozás jellemzően vásárolt gyümölcsből, kereskedelmi céllal készíti az alkoholos italt. A kereskedelmi főzdék általában bérföző tevékenységet is folytatnak. A jogszabályok alapján az otthon, illetve bérfözdékben elő́llított termékeket csak párlatnak lehet nevezni, pálinkának - néhány kivételtől eltekintve - csak a kereskedelmi fözdékben készült italok hívhatók.

A tanulmányban egy pálinkavásárlási preferenciákat vizsgáló, diszkrét választási kísérlet (discrete choice experiment, DCE) adatait modellezzük, egy szakmai és statisztikai szempontból is megalapozott modell felépítésére fektetve hangsúlyt. Tökéletes diszkrét választási modellt felépíteni sokkal inkább müvészet, mint tudomány. Ennek oka, hogy a standard modellilleszkedési mutatók ugyan egyes esetekben javulásra utalnak, az azokból levont következtetések azonban nem tükrözik a valóságot. Továbbá az is előfordulhat, hogy a különböző indikátorok értékei egymásnak ellentmondanak. Következésképpen célszerủ lépésről lépésre haladva, többféle szempont együttes figyelembevételével felépíteni a végső modellt 
(Apollo [2021]). Elemzésünk során egy standard multinomiális logit (MNL) specifikációt fogunk bővíteni különböző magyarázó változók kölcsönhatásaival (interakcióival). Az egyes interakciókkal fokozatosan kiegészített modellt két szempont szerint is összehasonlítjuk a korábban becsülttel/becsültekkel. Elsőként a modellek illeszkedését vetjük össze többféle mutató alapján, majd a „beemelt” interakciókra számított együtthatók valóságtartalmát teszteljük úgy, hogy az az alapján tett megállapítás(oka)t a korábbi kutatások eredményeivel ütköztetjük.

Az interakciók beemelése a választási modellekbe és ezáltal a preferenciaheterogenitás kezelése számos szerző tanulmányában megjelenik. Janssen és Hamm [2012] például a biotermékek teljes fogyasztói kiadáson belüli részesedését, Wägeli, Janssen és Hamm [2016] a biotakarmány-importtal kapcsolatos információtartalmat, Bronnmann és Asche [2017] a vásárlók nemét, életkorát, jövedelemszintjét, legmagasabb iskolai végzettségét, illetve egyéb szociodemográfiai jellemzőit, Wang, Ge és $M a$ [2018] a nemüket, életkorukat és legmagasabb iskolai végzettségüket, míg Macdiarmid et al. [2021] a nemüket, jövedelmüket, ízzel kapcsolatos elvárásaikat, valamint környezetvédelmi egyesületi tagságukat vonták be interakciókon keresztül a modellezésükbe. A hivatkozott szerzők azonban nem több szempont alapján hasonlítják össze a bázis- (tehát az interakciókat nem tartalmazó) és a kibővített modelleket.

A pálinkaágazat vizsgálatára Magyarországon eddig még senki sem hajtott végre DCE-t, de számos szerző elemezte azokat a termékattribútumokat, amelyek közül néhányat kísérletünkben mi is vizsgálunk. Korábbi tanulmányok (például OszKö Bt.-TNS [2003], GFK Hungária Piackutató Intézet [2008], NRC Kft. [2010]) rámutatnak, a pálinkafogyasztás hazánkban a 2000 -es évek elején alapvetően a tradícióhoz, nosztalgiához, magyarsághoz és a vidéki hangulathoz kötődött. Totth, Hlédik és Fodor [2011a] fogyasztói interjúk segítségével feltárták a pálinkavásárlást leginkább befolyásoló tényezőket, melyek a következők: íz, csomagolás (ezen belül föként a dizájn), ár, alkoholtartalom és márka. A szerzők megállapítása szerint a válaszadók az ajándékba szánt italokért magasabb árat hajlandók fizetni, mint a saját fogyasztás céljából vett termékekért. Az ár egyesek számára a minőség megtestesítője, vagyis a magasabb árat jobb minőséggel kötik össze (és fordítva). 2011-ben a Zwack, a Fütyülős (nem valódi pálinka), a Rézangyal, valamint a Zsindelyes termékei voltak a leginkább kedveltek. A külső termékjegyeket (például a csomagolást) illetően eltért a fiatalabb és az idősebb fogyasztók ízlése. Az előbbiek a feltűnőbb, színesebb csomagolásra és a „frappáns szlogenre” szavaztak, míg az idősebbek inkább a szolid színeket és a letisztult, hagyományos formákat részesítették előnyben. Totth, Fodor és Hlédik [2011b] egy kérdöíves felmérés segítségével az alkalmanként, illetve a rendszeresen pálinkát fogyasztók preferenciáit és az általuk vásárolt termékek jellemzőit (márka, főzde, tájegység, íz, kiszerelés) is feltérképezték. A megkérdezettek 17 százaléka számára a Fütyülős volt a legismertebb márka, melyet a 
Szatmári Szilva és a Mézes Vilmos követett. Ez az eredmény rávilágít arra is, hogy a 2010-es évek elején sokan - csakúgy, mint napjainkban - nem tudták elkülöníteni a pálinkajellegü italokat a valódi pálinkától. DCE-nkben gönci termőtájról származó barackpálinkák szerepelnek. Ezt a termőtájat a megkérdezettek 4 százaléka részesíti előnyben, a fogyasztók 19 százalékánál pedig a „szóba jöhet még” kategóriába tartozik. A tájegységek közül egyébként csak néhányat (szatmári, kecskeméti, szabolcsi) ismernek kellően a válaszadók. Az ízt tekintve a szilva, a kajszibarack és a mézes körükben a legnépszerübb (a mézzel készült szeszes ital ugyanakkor a jogszabályok értelmében nem minősül pálinkának).

Az előbbi szerzők néhány évvel később (Totth et al. [2017]; Totth-Mezőné Oravecz-Zarándné Vámosi [2018a], [2018b]) azt igyekeztek feltárni, hogy változtak-e a magyar pálinkafogyasztók szokásai és preferenciái. Korábbi kutatásukhoz hasonlóan azt találták, hogy még mindig a szatmári, szabolcsi és kecskeméti a legismertebb és legkedveltebb pálinkaföző tájegység. Nem tapasztaltak nagy eltérést a favorit ízekre (szilva, barack, körte) vonatkozóan sem, ám a kevésbé népszerü ízek között - ellentétben a 2010-es eredményekkel - megjelentek a pálinkajellegủ szeszes italok (például a Fütyülős) is, jelezve a fogyasztók pálinkával kapcsolatos ismereteinek bővülését. Ezekkel az eredményekkel ellentétben jelentős változás ment végbe viszont a pálinkavásárlást befolyásoló döntési szempontokat illetően: a megkérdezettek 2018-ban a márkát tartották a legmeghatározóbbnak a termelői név és az azáltal garantált minőség előtt, amely 2011-ben még nem tartozott a fontosabb terméktulajdonságok közé.

Hasonlóan Totth et al.-hoz [2017], Szegedyné Fricz et al. [2017] is a pálinkavásárlók magatartását és szokásait tanulmányozták. Az általuk összeállított kérdőívet kitöltők (1 014 fö) föbb termékválasztási szempontoknak a gyümölcs típusát (4,31-os átlagérték az 5-fokozatú Likert-skálán), az ismerősök ajánlásait $(3,65)$ és az árat $(3,33)$ tekintik, melyeket az eredetvédelem $(3,18)$ követ. Az alkoholfok $(3,01)$, a pálinka elóállítója $(2,96)$, a palack színe és címkéje $(2,82)$, valamint az internetes vélemények $(1,80)$ csak alacsonyabb pontszámmal rendelkeznek. Korábbi kutatásokhoz hasonlóan e szerzők is megállapítják, hogy az ajándékba vásárolt pálinkáért a fogyasztók hajlandók magasabb árat fizetni.

Végezetül Mucha, Oravecz és Totth [2020] többtényezös attitüdmodelljét emeljük ki. Ez esetben a 626 válaszadó legfontosabb vásárlási szempontnak a minőséget tekintette, melyet az ár, a magyar eredet, a presztízs és a divat követ. A szerzők, bár fontos tényezőnek találják, a márkát nem vizsgálták, mivel az a házi párlat vonatkozásában nem értelmezhető. 
A pálinkavásárlással és -fogyasztással foglalkozó föbb tanulmányok, valamint az általuk vizsgált vásárlási ismérvek és terméktulajdonságok

(Key studies on the purchase and consumption of pálinka [palinka], and the purchase criteria and product characteristics examined by them)

\begin{tabular}{|c|c|c|c|}
\hline Szerző & $\begin{array}{l}\text { Felmérés } \\
\text { éve }\end{array}$ & $\begin{array}{c}\text { Célcsoport } \\
\text { és adatgyüjtési technika }\end{array}$ & $\begin{array}{c}\text { Vizsgált vásárlási } \\
\text { ismérv/terméktulajdonság }\end{array}$ \\
\hline Totth-Hlédik-Fodor [2011a] & 2010 & $\begin{array}{l}\text { Interjú olyan } 23 \text { év feletti } \\
\text { személyekkel ( } 80 \text { fö), akik a } \\
\text { felmérést megelőző } 3 \text { hónapban } \\
\text { fogyasztottak pálinkát }\end{array}$ & $\begin{array}{l}\text { Íz, csomagolás, ár, } \\
\text { alkoholtartalom, márka }\end{array}$ \\
\hline Totth-Fodor-Hlédik [2011b] & 2010 & $\begin{array}{l}\text { Kérdöíves felmérés } 23 \text { és } 60 \text { év } \\
\text { közötti, gazdaságilag aktív, } \\
\text { legalább alkalmanként pálinkát } \\
\text { fogyasztók ( } 1487 \text { fö) körében }\end{array}$ & $\begin{array}{l}\text { Márka/fözde, íz, tájegység, } \\
\text { kiszerelés }\end{array}$ \\
\hline Totth et al. [2017] & 2016 & $\begin{array}{l}\text { Kérdőíves felmérés } 18 \text { év feletti, } \\
\text { legalább alkalmanként alkoholt } \\
\text { vásárló személyek (1 } 550 \text { fö) } \\
\text { körében }\end{array}$ & Íz, tájegység \\
\hline $\begin{array}{l}\text { Totth-Mezőné Oravecz- } \\
\text { Zarándné Vámosi [2018a] }\end{array}$ & 2016 & $\begin{array}{l}\text { Kérdöíves felmérés } 23 \text { és } 60 \text { év } \\
\text { közötti, gazdaságilag aktív, } \\
\text { legalább alkalmanként pálinkát } \\
\text { fogyasztók (1 } 500 \text { fö) körében }\end{array}$ & Ár, íz, tájegység \\
\hline Szegedyné Fricz et al. [2017] & 2017 & $\begin{array}{l}\text { Kérdőíves felmérés } 18 \text { év feletti } \\
\text { válaszadók ( } 1014 \text { fö) körében }\end{array}$ & $\begin{array}{l}\text { Gyümölcs típusa (íz), } \\
\text { ismerősök ajánlásai, ár, } \\
\text { eredetvédelem (földrajzi } \\
\text { jelzés), alkoholfok, } \\
\text { pálinka előállítója, palack } \\
\text { színe és címkéje, } \\
\text { internetes vélemények }\end{array}$ \\
\hline $\begin{array}{l}\text { Totth-Mezöné Oravecz- } \\
\text { Zarándné Vámosi [2018b] }\end{array}$ & 2018 & $\begin{array}{l}\text { Interjú olyan } 23 \text { év feletti } \\
\text { személyekkel ( } 67 \text { fő), akik a } \\
\text { felmérést megelőző } 3 \text { hónapban } \\
\text { fogyasztottak pálinkát }\end{array}$ & $\begin{array}{l}\text { Márka, termelői név, } \\
\text { megjelenés (például } \\
\text { csomagolás, címke), ár, } \\
\text { íz, származási hely, } \\
\text { alkoholtartalom, } \\
\text { elérhetőség, kiszerelés }\end{array}$ \\
\hline $\begin{array}{l}\text { Mucha-Oravecz-Totth } \\
\text { [2020] }\end{array}$ & 2019-2020 & $\begin{array}{l}\text { Kérdőíves felmérés olyan } 18 \text { év } \\
\text { feletti válaszadók körében ( } 626 \text { fő), } \\
\text { akik a felmérést megelőző } \\
3 \text { hónapban fogyasztottak pálinkát. }\end{array}$ & $\begin{array}{l}\text { Minőség, ár, magyar eredet, } \\
\text { presztízs, divat }\end{array}$ \\
\hline
\end{tabular}

STATISZTIKAI SZEMLE, 100. ÉVFOLYAM 1. SZÁM 44-67. OLDAL DOI: 10.20311/stat2022.1.hu0044 


\section{Módszertan}

Jelen fejezetben a kutatásunk folyamatát és az általunk alkalmazott, fogyasztói preferenciákat értékelő eljárás módszertani kérdéseit fogjuk bemutatni.

\subsection{A kutatás folyamata}

Kutatásunkat 2021. április és június között hajtottuk végre pálinkát kedvelő magyar fogyasztók körében. Kérdöívünk négy részből állt, melyek közül a második a fogyasztói preferenciákat feltáró DCE céljára szolgált. A kérdőív kitölthető volt számítógépen és mobileszközökön is annak érdekében, hogy minél szélesebb körben érjük el a potenciális válaszadókat. Az általunk vizsgált öt termékjellemző (attribútum), melyeket szakirodalmi tájékozódás (lásd az 1. táblázatot), szakértőkkel tartott konzultációk és egy pilot felmérés alapján határoztunk meg, a következő: 1. márkajelzés, 2. földrajzi jelzés, 3. készítési mód, 4. alkoholtartalom és 5. ár. A döntési helyzeteket az ún. D-hatékony (D-efficient) kísérleti elrendezéssel alakítottuk ki az Ngene 1.2 szoftver segítségével pilot felmérésünkhöz (Rose-Bliemer [2009], Choicemetrics [2018]). Itt a megkérdezett személyeknek nyolc hipotetikus helyzetben kellett dönteniük, melyek mindegyike három termékalternatívát és egy „,nem vásárol" opciót tartalmazott. Válaszaikat összegezve megállapítottuk, hogy az alkoholtartalom nem befolyásolja szignifikáns mértékben a fogyasztói döntéshozatalt, ezért e terméktulajdonságot a bayesi D-hatékony kísérleti elrendezés (Bliemer-RoseHess [2008]) összeállításakor már nem vettük figyelembe. A véglegesített kérdőívben 32 döntési helyzet szerepelt négy blokkba rendezve, így a pilot felméréshez hasonlóan egy-egy blokkban ekkor is mindössze nyolc választási szituációval szembesültek a válaszadók, és három pálinkaalternatíva, valamint a „nem vásárol” lehetőség közül választhattak. A termékopciókat a korábban felsorolt négy attribútum (tekintve, hogy az alkoholtartalmat kizártuk) jellemzi, melyek leírását a 2 . táblázat tartalmazza. 
A kisérletben vizsgált termékattribútumok

(Product attributes included in the experiment)

\begin{tabular}{|c|c|c|}
\hline \multicolumn{3}{|c|}{ Termékattribútum } \\
\hline megnevezése & leírása & megléte/szintje \\
\hline \multirow[t]{2}{*}{ Márkajelzés } & \multirow[t]{2}{*}{ Terméket előállító kereskedelmi főzde megnevezése } & Van (Bestillo) \\
\hline & & Nincs \\
\hline \multirow[t]{2}{*}{ Földrajzi jelzés } & \multirow[t]{2}{*}{ Gönci barackpálinka földrajzi jelzésének feltüntetése } & Van (Gönci barackpálinka) \\
\hline & & Nincs \\
\hline \multirow[t]{2}{*}{ Készítés módja } & \multirow[t]{2}{*}{ Kisüsti lepárlási mód feltüntetése } & Van (Kisüsti) \\
\hline & & Nincs \\
\hline \multirow[t]{4}{*}{ Ár } & \multirow[t]{4}{*}{ 0,5 1 ürtartalmú palack ára } & $4990 \mathrm{Ft}$ \\
\hline & & $8990 \mathrm{Ft}$ \\
\hline & & $12990 \mathrm{Ft}$ \\
\hline & & $16990 \mathrm{Ft}$ \\
\hline
\end{tabular}

A kérdőívben szereplö hipotetikus döntési helyzetekre a következő példát mutatjuk be:

„Kérem, jelölje meg, hogy melyik pálinkát vásárolná meg (1-3. opciók), vagy hogy nem vásárolná meg egyiket sem (4. opció)!”3

Lehetséges válaszok:

1. Kisüsti Gönci barackpálinka, 16990 Ft/0,5 l;

2. Bestillo barackpálinka, $4990 \mathrm{Ft} / 0,5 \mathrm{l}$;

3. Gönci barackpálinka, $16990 \mathrm{Ft} / 0,5 \mathrm{l}$;

4. Ezek közül egyiket sem választanám.

A kísérletben résztvevők átlagos életkora 54,73 év volt, további jellemzőiket, a minta részleteit a 3 . táblázat ismerteti.

Az 1000 fő bevonásával végzett felmérésben kitöltött kérdőívek közül az adattisztítás (a hiányos vagy a nem megfelelően kitöltött kérdőívek kizárása) után 760-at tudtunk értékelni. A minta nagyobb részét, csaknem kétharmadát férfiak (föként idősebbek) alkotják, amely összhangban van más szakirodalmi eredményekkel (például Szegedyné Fricz et al. [2017], Totth-Mezöné Oravecz-Zarándné Vámosi [2018a]).

${ }^{3}$ A felmérésben a döntési opciókat vizuálisan jelenítettük meg. A ,gönci barackpálinka” megnevezés esetén a választási lehetőséget jelképező pálinkás palackon az Európai Unió földrajzi árujelző logója is szerepelt.

STATISZTIKAI SZEMLE, 100. ÉVFOLYAM 1. SZÁM 44-67. OLDAL DOI: 10.20311/stat2022.1.hu0044 
A minta bemutatása

(Description of the sample)

\begin{tabular}{l|c}
\hline \multicolumn{1}{c|}{ Mintajellemző } & Szám/megoszlás \\
\hline \multicolumn{2}{c}{ Válaszadók száma (fö) } \\
\hline Adattisztítás előtt & 1000 \\
\hline Adattisztítás után & 760 \\
\hline Egy háztartásban & 2,77 \\
\hline
\end{tabular}

\begin{tabular}{l|c}
\multicolumn{2}{c}{ Válaszadók megoszlása (\%) } \\
\hline Nem & 36,45 \\
\hline Nö & 63,55 \\
\hline Férfi & \\
\hline Lakóhely & 26,45 \\
\hline Község & 40,92 \\
\hline Város & 32,63 \\
\hline Nagyváros & \\
\hline Végzettség & 2,37 \\
\hline Alapfokú végzettség & 43,42 \\
\hline Középfokú végzettség & 54,21 \\
\hline Felsőfokú végzettség & \\
\hline
\end{tabular}

Forrás: Saját szerkesztés a felmérés alapján.

\subsection{Az alkalmazott módszertan}

A DCE a (válaszadó által) feltárt preferenciát (stated preference, SP) mérő módszerek családjába tartozik több olyan gyakorta alkalmazott preferenciaértékelő eljárás mellett, mint a conjoint elemzés vagy a legjobb-legrosszabb skálázás (bestworst scaling) (Louviere-Flynn-Carson [2010]). A véletlen hasznosság elméletén ${ }^{4}$ (random utility theory, RUT) alapul, amelynek egyik eleme a hasznosságfüggvény, ami az (1) egyenlet szerint egy szisztematikus (megfigyelhetö) és egy véletlen komponensböl tevődik össze (McFadden [1974], Ben-Akiva-Lerman [1985]):

$$
U_{n, i, t}=V_{n, i, t}+\varepsilon_{n, i, t},
$$

\footnotetext{
${ }^{4}$ A döntéshozók mindig azt a lehetőséget választják, amely az egyéni hasznosságukat maximalizálja.
} 
ahol $n$ a döntéshozót, $i$ az alternatívát, $t$ a választási helyzetet, $U$ a teljes hasznosságot, $V$ a hasznosság szisztematikus részét, $\varepsilon$ pedig a hasznosság véletlen komponensét jelöli.

A MNL-modell az egyik legnépszerübb diszkrét választási modell (McFadden [1974]), amelynek alkalmazását számos előnyös tulajdonsága mellett több korlát is befolyásolja. Az utóbbiak közül az egyik az az eset, amikor homogén preferenciákkal, azonos érzékenységi szinttel jellemzi a minta válaszadóit az elemzett termékvagy szolgáltatástulajdonságokat illetően. Ennek kiküszöbölésére számos egyéb modelltípus áll a kutatók rendelkezésére, de az említett korlát enyhíthető a különféle termék-/vásárlójellemzők interakcióinak MNL-modellbe való szisztematikus integrálásával is (Hess [2014]).

Kísérletünk esetében a következő hasznosságfüggvényt definiáltuk a MNLspecifikációra alapozva:

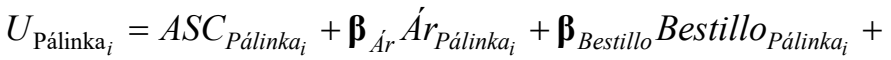

$$
\begin{aligned}
& +\boldsymbol{\beta}_{\text {Gönci } \text { Gönci } i_{\text {Pálinka }}}+\boldsymbol{\beta}_{\text {Kisissti } K_{\text {isüsti }} i_{\text {Pálinka }}}+\varepsilon_{\text {Pálinka }_{i}} \text {, }
\end{aligned}
$$

ahol $A S C$ a hasznosságfüggvény alternatívaspecifikus konstans tagját jelöli, amely a véletlen komponensre vonatkozó átlagértéket reprezentálja; $\boldsymbol{\beta}$ a vizsgált termékattribútumok hasznosságra gyakorolt hatását képviselő paramétervektort, Ár, Bestillo, Gönci és Kisüsti a megfigyelt változókat, $\varepsilon$ pedig a teljes hasznosság véletlen komponensét fejezi ki; ez utóbbiról feltételezzük, hogy Gumbel-eloszlást követ.

A legjobb modell kiválasztása érdekében az elemzők többféle információs kritériumot és tesztet is számításba vehetnek. Ezek egy része megengedőbb, míg más része szigorúbb a becsült paraméterek számát illetően. Az egyik legegyszerübb mutató, amely a modellek összehasonlításának alapjául szolgálhat, a log-likelihood függvény $(L L)$ konvergált értéke, illetve az abból számított pszeudo $R^{2}$ (HensherRose-Greene [2015]):

$$
\text { Pszeudo } R^{2}=1-\frac{L L(\text { konvergált })}{L L(0)} \text {, }
$$

ahol $L L$ (konvergált) a log-likelihood függvény konvergált értékét, $L L(0)$ pedig a loglikelihood függvény értékét jelöli abban az esetben, amikor modellünk mindössze konstanst tartalmaz.

A konvergált log-likelihood kisebb abszolút értéke jobb modellilleszkedésre utal, azonban nem szolgáltat információt arról, hogy az illeszkedést érintő javulás szignifikáns mértékü-e. Ennek vizsgálatára nyújt alternatívát az ún. likelihood-arány(likelihood-ratio, $L R$ ) teszt, amely a következő tesztstatisztikán alapul:

STATISZTIKAI SZEMLE, 100. ÉVFOLYAM 1. SZÁM 44-67. OLDAL DOI: 10.20311/stat2022.1.hu0044 


$$
\text { Tesztérték }=-2 *\left(L L_{\text {Bázismodell }}-L L_{\text {Bővitett modell }}\right) ; d f=p_{\text {Bázismodell }}-p_{\text {Bővitett modell }} \text {, }
$$

ahol a tesztérték a hipotézisvizsgálat tesztstatisztikájának értékét $\left(\chi^{2}\right), d f$ a szabadságfokot, $p$ pedig a modellek becsült paramétereinek számát jelöli (Train [2009]). Ha a próba szignifikáns, a bázismodellhez képest szignifikáns illeszkedésbeli javulást tapasztalunk.

A modellek összehasonlíthatóságát szolgálják még az Akaike-féle (Akaike information criterion, $A I C$; lásd az (5) egyenletet) és a bayesi információs kritériumok (Bayesian information criterion, BIC; lásd a (6) egyenletet) is (Mariel et al. [2021]).

$$
\begin{gathered}
A I C=-2 L L+2 p, \\
B I C=-2 L L+\operatorname{pln}(N),
\end{gathered}
$$

ahol $N$ a megfigyelések számát, pln $(N)$ a büntetőtagot jelöli.

A diszkrét választási modellépítés eredményeképpen kapott hasznossági együtthatókkal további kalkulációk végezhetők, melyek közül az egyik leggyakoribb a fizetési hajlandóság (willingness to pay, WTP) kiszámítása. Ehhez a (7) egyenlet összefüggését szükséges használnunk, míg a standard hibák meghatározásához a delta-módszer (Bliemer-Rose [2013]) nyújt alternatívát (lásd a (8) egyenletet).

$$
W T P_{\text {Márka }}=\frac{\boldsymbol{\beta}_{\text {Márka }}}{\boldsymbol{\beta}_{\text {Ar }}},
$$

ahol $W T P_{\text {Márka }}$ a márkára vonatkozó fizetési hajlandóságot, $\boldsymbol{\beta}_{\text {Márka }}$ és $\boldsymbol{\beta}_{A r}$ pedig a márka és az ár becsült hasznossági együtthatóit jelölik.

$$
\text { Standard hiba }\left(W T P_{\text {Márka }}\right)=\frac{1}{\boldsymbol{\beta}_{\text {Ar }}} \sqrt{\begin{array}{l}
\operatorname{var}\left(\boldsymbol{\beta}_{\text {Márka }}\right)-2 W T P_{\text {Márka }} \operatorname{cov}\left(\boldsymbol{\beta}_{\text {Márka }}, \boldsymbol{\beta}_{\text {Ar }}\right)+ \\
+W T P_{\text {Márka }}^{2} \operatorname{var}\left(\boldsymbol{\beta}_{\text {Ar }}\right)
\end{array}}
$$

A modellek becslését, illetve a különbözö információs kritériumok és WTPértékek számítását az R Apollo csomagjával végeztük (Hess-Palma [2019], [2021]; $R$ Core Team [2020]). 


\section{Eredmények}

Ebben a fejezetben a modellépítésünk folyamatát, a becsült együtthatók értelmezését, a megfelelő MNL-modellspecifikáció kiválasztását, valamint az arra kalkulált $W T P$-értékeket ismertetjük.

\subsection{A modellépítés folyamata, a becsült együtthatók értelmezése}

Adatelemzésünk első lépéseként egy (interakciókat nem tartalmazó) MNLbázismodellt becsültünk. Az eredményeket a 4. táblázatban foglaljuk össze.

4. táblázat

\begin{tabular}{|c|c|c|c|}
\hline \multirow{2}{*}{ Termékattribútum/modellt leíró mutató } & \multicolumn{3}{|c|}{ MNL-modell } \\
\hline & Együttható & $t$-érték & Standard hiba \\
\hline \multicolumn{4}{|c|}{ ASC (báziskategória: 1. alternatíva) } \\
\hline 2. alternatíva & 0,03 & 0,73 & 0,03 \\
\hline 3. alternatíva & 0,03 & 0,90 & 0,03 \\
\hline 4. alternatíva (Nem választ) & $-0,97 * *$ & $-15,19$ & 0,06 \\
\hline \multicolumn{4}{|c|}{ Márkajelzés (báziskategória: nincs márkajelzés) } \\
\hline Bestillo & $0,74 * *$ & 22,48 & 0,03 \\
\hline \multicolumn{4}{|c|}{ Földrajzi árujelző (báziskategória: nincs földrajzi árujelző) } \\
\hline Gönci & $0,88 * *$ & 25,81 & 0,03 \\
\hline \multicolumn{4}{|c|}{ Fözési mód (báziskategória: nincs főzés) } \\
\hline Kisüsti & $0,55 * *$ & 18,20 & 0,03 \\
\hline$A r(1000-$ rel osztva) & $-0,07 * *$ & $-19,60$ & $<0,01$ \\
\hline Kérdőívet kitöltők száma & \multicolumn{3}{|c|}{760} \\
\hline Megfigyelések száma & \multicolumn{3}{|c|}{6080} \\
\hline Paraméterek száma & \multicolumn{3}{|c|}{7} \\
\hline$L L(0)$ & \multicolumn{3}{|c|}{$-8428,67$} \\
\hline$L L($ konvergált) & \multicolumn{3}{|c|}{$-7270,33$} \\
\hline Pszeudo $R^{2}$ & \multicolumn{3}{|c|}{0,14} \\
\hline$A I C$ & \multicolumn{3}{|c|}{14554,66} \\
\hline$B I C$ & \multicolumn{3}{|c|}{14601,65} \\
\hline
\end{tabular}

$* * p<0,01$.

Megjegyzés. Itt és a további táblázatokban, ASC (alternative specific constant): alternatívaspecifikus konstans; LL (log likelihood): log-likelihood függvény; AIC (Akaike information criterion): Akaike-féle információs kritérium; BIC (Bayesian information criterion): bayesi információs kritérium. 
A 4. táblázatban közölt adatok szerint a „nem választ” opciót szignifikánsan kevesebbszer jelölték be a kérdőívet kitöltők a bázisként rögzített 1. alternatívához képest. A terméktulajdonságokra vonatkozó együtthatók alapján következtetésként levonható, hogy a válaszadók hasznosságérzetét a Gönci árujelző növeli a legnagyobb mértékben, melyet a Bestillo márkajelzés és a kisüsti fözési mód követnek. Az ár megítélése negatív, azaz annak emelkedése csökkenti a hasznosságérzetet.

Következő lépésként több lépcsőben kibővítettük a már bemutatott bázismodellünket. Különféle termék-/fogyasztóattribútum-interakciókat teszteltünk, míg nem találtunk 5 százalékos szinten szignifikáns hatásokat. A továbbiakban az ezekre vonatkozó eredményeket ismertetjük.

Elsőként a következő interakciót emeltük be a MNL-bázismodellbe:

$$
\boldsymbol{\beta}_{\text {Bestillo_új }}=\boldsymbol{\beta}_{\text {Bestillo }}+\boldsymbol{\beta}_{\text {Bestillo_Nagyváros }} * \text { Nagyváros, }
$$

ahol $\boldsymbol{\beta}_{\text {Bestill__ij }}$ az interakciós hatást is magában foglaló együtthatót, $\boldsymbol{\beta}_{\text {Bestillo_Nagyváros }}$ a modellbe bevont interakciós hatást, Nagyváros pedig annak - nem termékjellemzőhöz kapcsolódó - magyarázó változóját jelöli. Az így kapott modellre vonatkozó becslési eredményeket az 5 . táblázat ismerteti.

Az 5. táblázat alapján megállapítható, hogy a Bestillo_Nagyváros interakcióval kiegészített modell minden információs kritérium szerint jobb illeszkedést - alacsonyabb $L L$-, $A I C$ - és $B I C$-értéket - mutat a bázismodellhez képest. Ezt az LR-teszt eredménye is megerősíti $\left(\chi^{2}=45,04 ; d f=1 ; p<0,01\right)$, amely szignifikáns mértékü javulást jelez. A Bestillo_Nagyváros interakció modellegyütthatója rávilágít arra, hogy a nagyvárosiak jobban preferálják a Bestillo márkajelzéssel rendelkező termékeket, mint a nem nagyvárosban élők. A GFK Hungária Piackutató Intézet [2008] felmérése is azt erősíti meg, hogy a jogszabályok értelmében pálinkának számító italok fogyasztói jellemzően Budapesten és a nagyobb városokban élnek. Szegedyné Fricz et al. [2017] klaszteranalízis felhasználásával négy fogyasztói csoportot (érdeklődők, passzív elfogadók, pálinkakerülők, mindenivók) különítenek el, melyek másmás vásárlási és életmódbeli jellemzőkkel írhatók le. Az érdeklődők tipikusan Budapesten és más nagyvárosokban laknak, pálinkát a kereskedelemben (például a hipermarketekben vagy közvetlenül a fözdéktől) szereznek be. Jellemző rájuk továbbá, hogy az átlagnál tájékozottabbak az alkoholtartalmú termékek viszonylatában (pálinka és párlat elkülönítése, márkajelzések ismerete), és a pálinkához kulturális értéket is társítanak. A másik három csoport tagjai (passzív elfogadók, pálinkakerülők, mindenivók) rendszerint kisebb városokban, valamint községekben élnek, nem rendelkeznek mélyebb szintü ismeretekkel e téren, kereskedelmi egységekben nem igazán vásárolnak pálinkát (inkább ajándékba kapják vagy ismerőstől szerzik azt be), illetve nem értékelik olyan mértékben a minőségi termékeket és így a márkajelzéseket sem, mint az érdeklődők. Totth et al. [2017] a fiatal pálinkafogyasztók személyiségjellemzői alapján négy szegmenst határolnak le (független kreatívok, tradicionális 
értékrendet követők, együttérző boldogságkeresők, biztonságkeresők), amelyek fogyasztási szokásaikat és attitüdjeiket tekintve eltérnek egymástól. Az előbb bemutatott érdeklődők csoporthoz hasonlóan a független kreatívok jellemzően nagyobb városokban élnek, és szívesen kipróbálnak pálinkakülönlegességeket. Totth, Mezöné Oravecz és Zarándné Vámosi [2018a] tanulmányukban kiemelik, hogy a házi pálinka (párlat) népszerüsége a bolti forgalomban kapható márkás pálinkákhoz képest töretlen a vidéki lakosok körében - melyet rendszerint ismerősöktől vagy rokonoktól szereznek be/kapnak. Mindezek alapján nem meglepő, hogy a Bestillo márkajelzéssel ellátott termékeket inkább a nagyvárosi fogyasztók keresik szemben a nem nagyvárosi vásárlókkal, hiszen ők azok, akik nagy valószínüséggel ismerik e jelzéseket, és jobb minőséget is rendelnek azokhoz.

5. táblázat

Az 1. interakciós $M N L$-modellbecslés eredményei

(Estimation results of the MNL model with the first interaction)

\begin{tabular}{l|c|c|c}
\hline \multirow{2}{*}{ Termékattribútum/modellt leíró mutató } & \multicolumn{3}{|c}{ MNL-modell } \\
\cline { 2 - 4 } & Együttható & $t$-érték & Standard hiba \\
\hline \multicolumn{4}{|c}{$A S C$ (báziskategória: 1. alternatíva) } \\
\hline 2. alternatíva & 0,03 & 0,72 & 0,04 \\
\hline 3. alternatíva & 0,03 & 0,89 & 0,03 \\
\hline 4. alternatíva (Nem választ) & $-0,97^{* *}$ & $-15,17$ & 0,06 \\
\hline
\end{tabular}

Márkajelzés (báziskategória: nincs márkajelzés)

\begin{tabular}{l|c|c|c}
\multicolumn{4}{c}{ Márkajelzés (báziskategória: nincs márkajelzés) } \\
\hline Bestillo & $0,61 * *$ & 16,17 & 0,04 \\
\hline Bestillo_Nagyváros & $0,39 * *$ & 6,70 & 0,06 \\
\hline
\end{tabular}

Földrajzi árujelző (báziskategória: nincs földrajzi árujelző)

\begin{tabular}{|c|c|c|c|}
\hline Gönci & $0,88 * *$ & 25,78 & 0,03 \\
\hline
\end{tabular}

Fözési mód (báziskategória: nincs főzési mód)

\begin{tabular}{|c|c|c|c|}
\hline Kisüsti & $0,56 * *$ & 18,21 & 0,03 \\
\hline$A r$ (1 000 -rel osztva) & $-0,07 * *$ & $-19,59$ & $<0,01$ \\
\hline Kitöltők száma & \multicolumn{3}{|c|}{760} \\
\hline Megfigyelések száma & \multicolumn{3}{|c|}{6080} \\
\hline Paraméterek száma & \multicolumn{3}{|c|}{8} \\
\hline$L L(0)$ & \multicolumn{3}{|c|}{$-8428,67$} \\
\hline$L L($ konvergált) & \multicolumn{3}{|c|}{$-7247,81$} \\
\hline Pszeudo $R^{2}$ & \multicolumn{3}{|c|}{0,14} \\
\hline$A I C$ & \multicolumn{3}{|c|}{14511,62} \\
\hline$B I C$ & \multicolumn{3}{|c|}{14565,32} \\
\hline
\end{tabular}

$* * p<0,01$ 
Ezt követően modellünkbe egy újabb interakciós hatást is beépítettünk:

$$
\boldsymbol{\beta}_{\text {Gönci_üj }}=\boldsymbol{\beta}_{\text {Gönci }}+\boldsymbol{\beta}_{\text {Gönci_60év felett }} * 60 \text { év felett, }
$$

ahol $\boldsymbol{\beta}_{\text {Gönci_íj }}$ az újabb interakciós hatás $\boldsymbol{\beta}$-ját $\left(\boldsymbol{\beta}_{\text {Gönci_60év felett }}\right)$ is magában foglaló együtthatót, 60 év felett pedig az interakció - nem termékjellemzőhöz kapcsolódó magyarázó változóját jelöli. Az eredményekről a 6. táblázat ad áttekintést.

A 2. interakciós $M N L$-modellbecslés eredményei (Estimation results of the MNL model with the second interaction)

\begin{tabular}{l|c|c|c}
\hline \multirow{2}{*}{ Termékattribútum/modellt leíró mutató } & \multicolumn{3}{|c}{ MNL-modell } \\
\cline { 2 - 4 } & Együttható & $t$-érték & Standard hiba \\
\hline \multicolumn{4}{c}{ ASC (báziskategória: 1 . alternatíva) } \\
\hline 2. alternatíva & 0,03 & 0,73 & 0,04 \\
\hline 3. alternatíva & 0,03 & 0,90 & 0,03 \\
\hline 4. alternatíva (Nem választ) & $-0,97 * *$ & $-15,18$ & 0,06 \\
\hline
\end{tabular}

\begin{tabular}{l|c|c|c}
\multicolumn{4}{c}{ Márkajelzés (báziskategória: nincs márkajelzés) } \\
\hline Bestillo & $0,61^{* *}$ & 16,16 & 0,04 \\
\hline Bestillo_Nagyváros & $0,39^{* *}$ & 6,69 & 0,06 \\
\hline
\end{tabular}

Földrajzi árujelző (báziskategória: nincs földrajzi árujelző)

\begin{tabular}{l|c|c|c}
\hline Gönci & $0,83^{* *}$ & 19,83 & 0,04 \\
\hline Gönci_60 év felett & $0,12^{*}$ & 2,17 & 0,06 \\
\hline
\end{tabular}

\begin{tabular}{l|c|c|c}
\multicolumn{3}{c}{ Fözési mód (báziskategória: nincs fözési mód) } \\
\hline Kisüsti & $0,55^{* *}$ & 18,20 & 0,03 \\
\hline$A r(1000$-rel osztva) & $-0,07^{* *}$ & $-19,59$ & $<0,01$ \\
\hline Kitöltők száma & \multicolumn{3}{|c}{760} \\
\hline Megfigyelések száma & 6080 \\
\hline Paraméterek száma & \multicolumn{3}{|c}{9} \\
\hline$L L(0)$ & $-8428,67$ \\
\hline$L L($ konvergált) & \multicolumn{3}{|c}{$0,145,46$} \\
\hline Pszeudo $R^{2}$ & \multicolumn{3}{|c}{14508,92} \\
\hline$A I C$ & 14569,33 \\
\hline$B I C$ & \multicolumn{3}{|c}{} \\
\hline
\end{tabular}

$* p<0,05,{ }^{* *} p<0,01$ 
Az újabb interakció (Gönci_60 év felett) bevonása alapján nem lehet olyan egyértelmü következtetést levonni, mint az előző esetben. Itt a $L L$ és az $A I C$ értéke alacsonyabb, a $B I C$-é viszont magasabb, mint az 5. táblázatban látható értékek. Az LR-teszt eredménye $\left(\chi^{2}=4,70 ; d f=1 ; p=0,03\right)$ pedig 5 százalékos szinten szignifikáns javulást mutat a korábbi modellhez képest. A Gönci_60 év felett interakciós hatás $\beta$-jának pozitív előjele arra utal, hogy a 60 év feletti válaszadók inkább részesítik elönyben a Gönci földrajzi jelzést, mint az ennél fiatalabb korosztály. Ezt Totth et al. [2017] kutatása is alátámasztja, amely szerint a fiatalabb pálinkafogyasztók körében legismertebb pálinkaföző tájegységek a szatmári, szabolcsi és kecskeméti térség, mivel az ezekből származó pálinkákat csupán a válaszadók negyede nem ismeri. A gönci tájegységet ugyanakkor a megkérdezettek mindössze 3,6 százaléka részesíti előnyben italvásárlásai során. Az elmúlt évtizedekben megjelent tanulmányok szerzői (lásd például NRC Kft. [2010], Totth-Mezöné Oravecz-Zarándné Vámosi [2018a]) megállapítják, hogy a fiatalok a pálinkát barátokhoz köthető „kedvfokozónak” tekintik, ahhoz jó hangulatot, kellemes társaságot asszociálnak, míg az idősebbek családhoz füződő, egyfajta „szakrális” italnak tartják. A fiatalabb korosztály körében sokkal népszerübb a whisky és a vodka fogyasztása (Totth-Mezöné Oravecz-Zarándné Vámosi [2018a]). A pálinka mellett a boroknál (Botonaki-Tsakiridou [2004]) és az élelmiszereknél (Van Ittersum-Candel-Torelli [1999]) is megfigyelhető, hogy a földrajzi árujelzővel ellátott termékeket inkább az idősebb fogyasztók preferálják, akik akár magasabb árat is hajlandók ezekért fizetni. Összességében tehát nem meglepő, hogy a fiatalabb (föként a 18-39 év közötti) korosztály italválasztásakor nem a földrajzi jelzés, hanem az ár az elsődleges szempont, melynek következtében inkább az (akár olcsóbban beszerezhető) whiskyt, vodkát vagy házi „,pálinkát” (párlatot) részesítik előnyben.

Utolsó lépésben a kisüsti fözési mód és a legalább havi egyszeri fogyasztás interakcióját vizsgáljuk a következők szerint:

$$
\begin{aligned}
& \boldsymbol{\beta}_{\text {Kisüsti_új }}=\boldsymbol{\beta}_{\text {Kisüsti }}+ \\
& +\boldsymbol{\beta}_{\text {Kisüsti_Legalább havonta egyszer fogyaszt }} * \text { Legalább havonta egyszer fogyaszt, }
\end{aligned}
$$

ahol $\boldsymbol{\beta}_{\text {Kisuisti_ijj }}$ az újabb interakciós hatás $\boldsymbol{\beta}_{\text {-ját }}\left(\boldsymbol{\beta}_{\text {Kisüsti_Legalább havonta egyszer fogyaszt }}\right)$ is magában foglaló együtthatót, a Legalább havonta egyszer fogyaszt pedig az interakció - nem termékjellemzőhöz kapcsolódó - magyarázó változóját jelöli. E modellbecslésünk eredményeit a 7. táblázat ismerteti. 
A 3. interakciós $M N L$-modellbecslés eredményei

(Estimation results of the MNL model with the third interaction)

\begin{tabular}{l|c|r|c}
\hline \multirow{2}{*}{ Termékattribútum/modellt leíró mutató } & \multicolumn{3}{|c}{ MNL-modell } \\
\cline { 2 - 4 } & Együttható & \multicolumn{1}{|c}{$t$-érték } & Standard hiba \\
\hline \multicolumn{4}{|c}{ ASC (báziskategória: 1. alternatíva) } \\
\hline 2. alternatíva & 0,03 & 0,72 & 0,04 \\
\hline 3. alternatíva & 0,03 & 0,89 & 0,03 \\
\hline 4. alternatíva (Nem választ) & $-0,97^{* *}$ & $-15,18$ & 0,06 \\
\hline
\end{tabular}

Márkajelzés (báziskategória: Nincs márkajelzés)

\begin{tabular}{l|r|r|c}
\multicolumn{4}{c}{ Márkajelzés (báziskategória: Nincs márkajelzés) } \\
\hline Bestillo & $0,61^{* *}$ & 16,17 & 0,04 \\
\hline Bestillo_Nagyváros & $0,39^{* *}$ & 6,70 & 0,06 \\
\hline
\end{tabular}

Földrajzi árujelzö (báziskategória: Nincs földrajzi árujelző)

\begin{tabular}{l|c|c|c}
\multicolumn{4}{c}{ Földrajzi árujelzö (báziskategória: Nincs földrajzi árujelzö) } \\
\hline Gönci & $0,83^{* *}$ & 19,82 & 0,04 \\
\hline Gönci_60 év felett & $0,12^{*}$ & 2,18 & 0,06 \\
\hline
\end{tabular}

\begin{tabular}{|c|c|c|c|}
\hline \multicolumn{4}{|c|}{ Fözési mód (báziskategória: Nincs főzési mód) } \\
\hline Kisüsti & $0,48 * *$ & 10,35 & 0,05 \\
\hline Kisüsti_Legalább havonta egyszer fogyaszt & $0,12 *$ & 2,05 & 0,06 \\
\hline$A r(1000$-rel osztva) & $-0,07 * *$ & $-19,59$ & $<0,01$ \\
\hline Kitöltők száma & \multicolumn{3}{|c|}{760} \\
\hline Megfigyelések száma & \multicolumn{3}{|c|}{6080} \\
\hline Paraméterek száma & \multicolumn{3}{|c|}{10} \\
\hline$L L(0)$ & \multicolumn{3}{|c|}{$-8428,67$} \\
\hline$L L($ konvergált) & \multicolumn{3}{|c|}{$-7243,36$} \\
\hline Pszeudo $R^{2}$ & \multicolumn{3}{|c|}{0,14} \\
\hline AIC & \multicolumn{3}{|c|}{14506,71} \\
\hline$B I C$ & \multicolumn{3}{|c|}{14573,84} \\
\hline
\end{tabular}

$* p<0,05,{ }^{* *} p<0,01$.

A 7. táblázat eredményei alapján az előző esetben levont következtetésünket erősíthetjük meg, miszerint az újabb interakció bevonásával nincs egyértelmü illeszkedésbeli javulás. Habár a $L L$ (konvergált) és az AIC értéke alacsonyabb (jobb illeszkedés), a $B I C$-é magasabb (rosszabb illeszkedés). Az LR-teszt eredménye a 2. interakciós (Gönci_60 év felett) MNL-modellbecslés LR-tesztjének eredményéhez hasonló $\left(\chi^{2}=4,20 ; \bar{d} f=1 ; p=0,04\right)$, tehát a komplexebb modell 5 százalékos szignifikanciaszint mellett jelentős javulást mutat. A becsült interakciós $\boldsymbol{\beta}$ együttható alapján megállapítható, hogy a havi egy vagy annál több alkalommal pálinkát fogyasztók inkább a kisüsti főzési módot preferálják. Magyarországon a kereskedelmi főzdék 
legtöbbje a magasabb bekerülési értékü, modernebb tornyos lepárlást alkalmazza, az olcsóbb kisüsti fözési mód inkább a bérfözdékre jellemző (Harcsa [2017a], Kassai et al. [2016], Káposzta-Ritter-Kassai [2015]), ami föként a két fözdetípus közötti különbségböl ered (Kassai et al. [2016], Török-Maró [2020]). Más kutatások a két lepárlási módot csupán a fogyasztói ízlést tekintve hasonlítják össze. Géczi et al. [2018] „vakíztesztjei” alapján a pálinka elkészítését követő 1,5-2 évben a tornyos lefözéssel készült pálinkákat találják ízletesebbnek a vásárlók, 2 év után pedig a kisüsti technológiával készülteket. A tornyos technológiával elöállított, illatosabb pálinkákat a fiatalabbak, azon belül is főként a nők választották a szerzők által végzett tesztekben, a kisüsti technológiával készült termékeket pedig elsősorban az idősebb férfiak. Harcsa [2017b] megállapítja, hogy a pálinkaversenyeken a tornyos lepárlással készült pálinkák az eredményesebbek és kedveltebbek.

\subsection{A megfelelő specifikáció kiválasztása}

A modellek összehasonlítására szolgáló, korábban bemutatott mutatókat az ábrán foglaljuk össze.

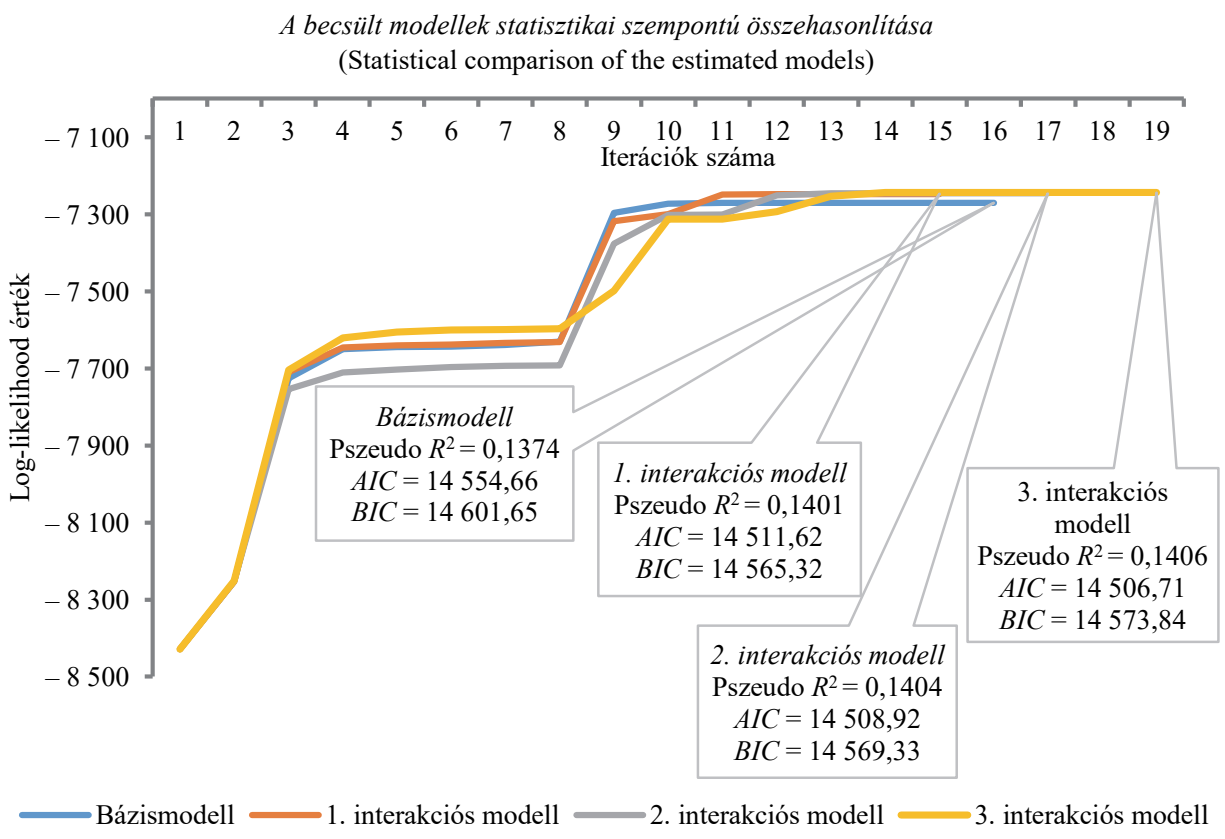

Megjegyzés. LR-teszt (bázismodell - 1. interakciós modell): $p<0,01$; LR-teszt (1. interakciós modell 2. interakciós modell): $p=0,03$; LR-teszt (2. interakciós modell - 3. interakciós modell): $p=0,04$. A magasabb pszeudo $R^{2}$, a $L L$ alacsonyabb abszolút értéke, illetve az $A I C$ és a $B I C$ alacsonyabb értéke a modellek jobb illeszkedésére utal.

STATISZTIKAI SZEMLE, 100. ÉVFOLYAM 1. SZÁM 44-67. OLDAL DOI: 10.20311/stat2022.1.hu0044 
Az ábrán látható, hogy a bázismodellhez képest minden interakciós MNLmodell jobban teljesít. Az utóbbi specifikációk összevetéséből ugyanakkor nem vonható le az a következtetés, hogy újabb és újabb paraméterek bevonása jobb illeszkedéshez vezet. A 2. interakciós modell kedvezőbb pszeudo $R^{2}$ - és $A I C$-értékkel rendelkezik, mint az 1., azonban $B I C$-ja magasabb, ami gyengébb illeszkedésre utal. Ehhez hasonlóan a 3. MNL-specifikáció pszeudo $R^{2}$ - és $A I C$-értéke is jobb illeszkedést mutat a 2. és az 1. modellekhez képest, de $B I C$-ja magasabb mindkettőénél. Az LR-tesztek eredményei szerint viszont 5 százalékos szignifikanciaszint mellett minden esetben jelentős mértékü javulás mutatható ki az egyre komplexebb modellek javára. (Lásd az ábra megjegyzésrovatát.) Mindezen statisztikai szempontok alapján két modell közül célszerü választanunk. Az egyik az 1. interakciós modell, amely esetén a legalacsonyabb $B I C$-értéket tapasztaljuk, míg a másik a 3. interakciós modell, amelynek pszeudo $R^{2}$-e a legmagasabb, $A I C$-ja pedig a legalacsonyabb. Mivel a BIC-mutató kritikái közé tartozik, hogy az egyszerúbb (kevesebb paramétert becslö) modellt „,preferálja” (lásd például Burnham-Anderson [2002]), a végső modell kiválasztása elött érdemes megvizsgálni, hogy a 3. kibővített specifikáció becsült interakciós együtthatói mennyire felelnek meg a valóságnak. Az előző alfejezetben már kiemeltük, hogy a fogyasztás és a fözési mód speciális kapcsolatáról nem áll rendelkezésre elegendő bizonyíték, ezért mind módszertani, mind pálinkaszakmai szempontokat figyelembe véve az 1. interakciós modell kiválasztása és további elemzése mellett kell, hogy döntsünk.

\title{
2.3. Fizetési hajlandóságra vonatkozó kalkulációk az 1. interakciós modell esetén
}

A legjobb specifikációnak tekintett 1 . interakciós modell WTP-kalkulációinak eredményeit a 8 . táblázat tartalmazza.

\author{
8. táblázat
}

A fizetésihajlandóság-kalkulációk eredményei az 1. interakciós MNL-modell esetében (Results of WTP-calculations for the MNL model with the first interaction)

\begin{tabular}{l|r|r|c}
\hline \multicolumn{1}{|c|}{ Termékattribútum } & $\begin{array}{c}\text { Fizetési hajlandóság } \\
(\mathrm{Ft} / 0,5 \mathrm{l})\end{array}$ & $t$-érték & Standard hiba \\
\hline Bestillo & $8626^{* *}$ & 11,07 & 779,4 \\
\hline Bestillo_Nagyváros & $5489^{* *}$ & 4,03 & 1364,0 \\
\hline Gönci & $12410^{* *}$ & 13,13 & 945,1 \\
\hline Kisüsti & $7813^{* *}$ & 11,27 & 693,0 \\
\hline
\end{tabular}

Megjegyzés. ** $p<0,01$. 
A 8. táblázat alapján a kérdőívet kitöltők hozzávetőlegesen 12410 Ft-tal többet hajlandók fizetni a Gönci jelzésủ pálinkáért a földrajzi jelzővel nem rendelkező termékhez képest. Mindemellett a válaszadók megközelítőleg 7813 Ft-tal magasabb összeget adnának a kisüsti pálinkáért, a nagyvárosban élők (a nem nagyvárosi kitöltőkhöz képest) pedig körülbelül 5489 Ft-tal fizetnének többet, ha az ital Bestillo márkajelzéssel rendelkezne.

\section{Következtetések}

Tanulmányunkban egy DCE-t mutattunk be, amely a pálinka iránt érdeklődő fogyasztók preferenciáit vizsgálta. A kísérlet eredményeinek ismertetésén túl azt is célul tüztük ki, hogy iránymutatást adjunk az olvasók számára a diszkrét választási modellek felépítését és a közülük való választást illetően.

Elöször a kísérlet részleteibe (a kísérleti elrendezésbe, az adatfelvétel folyamatába és a mintánk összetételébe) adtunk betekintést, említést téve a vizsgálandó termékattribútumok meghatározását megalapozó pilot kutatásról is. Ezt követően a modellezési megközelítésünket, a modellspecifikációkkal kapcsolatos döntések során figyelembe vett információs kritériumokat, valamint a fizetési hajlandóságra vonatkozó kalkuláció leírását ismertettük. Eredményeink bemutatása során egy bázismodellből indultunk ki, majd abból egyre komplexebb modelleket építettünk különféle termék- és fogyasztói jellemzőkből képzett interakciók integrálásával. A modellek mindegyikét ezután összehasonlítottuk, és a becslési eredmények valóságtartalmát a szakirodalommal ütköztetve ellenőriztük. Az információs kritériumok alapján két interakcióval bővített modellt ítéltünk kiválónak, az elsőt (a bázismodell lakóhelymárkajelzés interakcióval bővített változatát) és a harmadikat (a pálinkafogyasztás gyakorisága-fözés módja interakcióval kiegészített második modellt), melyek közül az előbbit tudtuk szakmailag leginkább alátámasztani. Így a továbbiakban a fizetési hajlandóságra vonatkozó kalkulációkat erre végeztük el.

Vizsgálatunk során arra a következtetésre jutottunk, hogy a pálinkafogyasztók a Gönci földrajzi jelzéssel és a Bestillo márkajelzéssel rendelkező, valamint a kisüsti főzési móddal készült termékeket részesítik előnyben. A Bestillo márkajelzés iránti preferencia a nagyvárosi fogyasztók körében hangsúlyosabb, amit korábban megjelent tanulmányok (többek között GFK Hungária Piackutató Intézet [2008], Szegedyné Fricz et al. [2017], Totth et al. [2017]) is megerősítenek. E fogyasztói csoport rendszerint kereskedelmi egységekben vásárol pálinkát, és az átlagosnál tájékozottabb az alkoholos italokkal kapcsolatban (például ismeri a tipikus márkajel-

STATISZTIKAI SZEMLE, 100. ÉVFOLYAM 1. SZÁM 44-67. OLDAL DOI: 10.20311/stat2022.1.hu0044 
zéseket, pálinkafőzési módokat), a márkajelzésekkel ellátott termékekhez magasabb minőséget társít, továbbá szívesen fogyaszt pálinkakülönlegességeket, és fizet magasabb árat is ezekért. A házi pálinka (párlat) népszerüsége azonban vidéken, illetve a kisebb városokban továbbra is töretlen (például Totth-Mezöné OraveczZarándné Vámosi [2018b]), így az ezeken a helyeken élők kisebb valószínüséggel fogyasztanak márkajelzéssel ellátott pálinkát.

Tanulmányunk további fontos konklúziója, hogy nem elég csupán statisztikai szempontokat figyelembe venni a modellépítés során, minden esetben szükség van az eredmények valóságtartalmának vizsgálatára is.

\section{Irodalom}

APOLLO [2021]: Apollo Choice Modelling Forum. http://www.apollochoicemodelling.com/ forum/viewtopic.php? $\mathrm{f}=23 \& \mathrm{t}=290$

Ben-Akiva, M. - Lerman, S. R. [1985]: Discrete Choice Analysis: Theory and Application to Travel Demand (Transportation Studies). MIT Press. Cambridge.

Bliemer, M. C. J. - Rose, J. M. - Hess, S. [2008]: Approximation of Bayesian efficiency in experimental choice designs. Journal of Choice Modelling. Vol. 1. No. 1. pp. 98-126. https://doi.org/10.1016/S1755-5345(13)70024-1

Bliemer, M. C. J. - Rose, J. M. [2013]: Confidence intervals of willingness-to-pay for random coefficient logit models. Transportation Research Part B: Methodological. Vol. 58. December. pp. 199-214. https://doi.org/10.1016/j.trb.2013.09.010

BotonaKi, A. - TSAKIRIDOU, E. [2004]: Consumer response evaluation of a Greek quality wine. Acta Agriculturae Scandinavica, Section C - Food Economics. Vol. 1. No. 2. pp. 91-98. https://doi.org/10.1080/16507540410024515

Bronnmann, J. - Asche, F. [2017]: Sustainable seafood from aquaculture and wild fisheries: Insights from a discrete choice experiment in Germany. Ecological Economics. Vol. 142. December. pp. 113-119. https://doi.org/10.1016/j.ecolecon.2017.06.005

Burnham, K. P. - Anderson, D. R. [2002]: Model Selection and Multimodel Inference: A Practical Information-Theoretic Approach. Second Edition. Springer. New York.

ChoiceMetrics [2018]: Ngene 1.2 User Manual \& Reference Guide. http://www.choicemetrics.com/NgeneManual120.pdf.

EuRÓPA BizotTSÁg [2021]: eAmbrosia, the EU Geographical Indications Register (eAmbrosia, az EU földrajzi jelzéseinek regisztere). https://ec.europa.eu/info/food-farming-fisheries/foodsafety-and-quality/certification/quality-labels/geographical-indications-register/

EuRÓPai Unió Hivatalos Lapja [2008]: Az Európai Parlament és a Tanács 110/2008/EK rendelete (2008. január 15.) a szeszes italok meghatározásáról, megnevezéséröl, kiszereléséről, címkézésérôl és földrajzi árujelzöinek oltalmáról, valamint az 1576/89/EK tanácsi rendelet hatályon kivül helyezéséröl. L 39. Február 13. 16-54. old. https://eur-lex.europa.eu/legalcontent/HU/TXT/PDF/?uri=CELEX:32008R0110\&from=HU 
GFK HungÁRIA Piackutató InTÉZet [2008]: Piackutatás a pálinka népszerüsitö kampány megalapozására. Budapest.

HARCSA I. M. [2018]: A pálinkafözés gazdasági hatásai. Doktori disszertáció. Debreceni Egyetem. Debrecen.

HARCSA, I. M. [2017a]: Study on the potential of subcontract palinka distillation. Economics of Agriculture. Vol. 64. No. 4. pp. 1379-1391. https://doi.org/10.5937/ekoPolj1704379H

HARCSA, I. M. [2017b]: Energy demand for pálinka production and some practical issues of waste treatment. Economic and Regional Studies/Studia Ekonomiczne i Regionalne. Vol. 10. No. 3. pp. 82-95. https://doi.org/10.2478/ers-2017-0027

Hensher, D. A. - Rose, J. M. - Greene, W. H. [2015]: Applied Choice Analysis. Cambridge University Press. Cambridge.

Hess, S. - PALMA, D. [2019]: Apollo: A flexible, powerful and customisable freeware package for choice model estimation and application. Journal of Choice Modelling. Vol. 32. September. Article No. 100170. https://doi.org/10.1016/j.jocm.2019.100170

HeSs, S. - PALMA, D. [2021]: Apollo version 0.2.4 - User Manual. www.ApolloChoiceModelling.com.

Hess, S. [2014]: Latent class structures: Taste heterogeneity and beyond. In: Hess, S. Daly, A. (eds.): Handbook of Choice Modelling. Edward-Elgar Publishing. London. pp. 311-332.

JANSSEN, M. - HAMM, U. [2012]: Product labelling in the market for organic food: Consumer preferences and willingness-to-pay for different organic certification logos. Food Quality and Preferences. Vol. 25. No. 1. pp. 9-22. https://doi.org/10.1016/j.foodqual.2011.12.004

KÁPOSZTA J. - RitTeR K. - KASSAI Z. [2015]: Hungarikumok területi jelentőségének vizsgálata, különös tekintettel a pálinkára. Tér és Társadalom. 29. évf. 4. sz. 139-153. old. https://doi.org/10.17649/TET.29.4.2707

KASSAI, Z. - KÁPOSZTA, J. - RitTER, K. - DÁVID, L. - NAGY, H. - FARKAS, T. [2016]: The territorial significance of food Hungaricums: The case of pálinka. Romanian Journal of Regional Science. Vol. 10. No. 2. pp. 64-84.

LOUVIERE, J. J. - FlynN, T. N. - CARSON, R. T. [2010]: Discrete choice experiments are not conjoint analysis. Journal of Choice Modelling. Vol. 3. No. 3. pp. 57-72. https://doi.org/10.1016/ S1755-5345(13)70014-9

Macdiarmid, J. I. - Cerroni, S. - Kalentakis, D. - Reynolds, C. [2021]: How important is healthiness, carbon footprint and meat content when purchasing a ready meal? Evidence from a non-hypothetical discrete choice experiment. Journal of Cleaner Production. Vol. 282. Article No. 124510. https://doi.org/10.1016/j.jclepro.2020.124510

MAGYAR ÉlelmiszerKöNYv BizotTSÁg [2002]: Magyar Élelmiszerkönyv (Codex Alimentarius Hungaricus). http://elelmiszerlanc.kormany.hu/magyar-elelmiszerkonyv

MAGYAR KÖZLÖNY [2008]: 2008. évi LXXIII. törvény a pálinkáról, a törkölypálinkáról és a Pálinka Nemzeti Tanácsról. 164 sz. November 20. 20002-20005. old. http://www.kozlonyok.hu/ nkonline/MKPDF/hiteles/Mk08164.pdf

MAGYAR KÖZLÖNY [2012]: 2012. évi XXX. törvény a magyar nemzeti értékekröl és a hungarikumokról. 42. sz. Április 11. 8116-8122. old. http://www.kozlonyok.hu/nkonline/ mkpdf/hiteles/mk12042.pdf 
MAGYAR KÖZLÖNY [2016]: 2016. évi LXVIII. törvény a jövedéki adóról. 88. sz. Június 17. 6726-6792. old. http://www.kozlonyok.hu/nkonline/MKPDF/hiteles/mk16088.pdf

Mariel, P. - Hoyos, D. - Meyerhoff, J. - CzAjkowski, M. - Dekker, T. - Glenk, K. Jacobsen, J. B. - Liebe, U. - Olsen, S. B. - SAgebiel, J. - Thiene, M. [2021]: Environmental Valuation with Discrete Choice Experiments. Springer Nature. Cham.

MCFADDEN, D. [1974]: Conditional logit analysis of qualitative choice behavior. In: Zarembka, P. (ed.): Frontiers in Econometrics. Academic Press. New York. pp. 105-142.

Mucha L. - Oravecz T. - TotTh G. [2020]: A fogyasztói attitüd kognitív komponensének a pálinka imázsában betöltött szerepe. Táplálkozásmarketing. 7. évf. 2. sz. 21-32. old. https://doi.org/10.20494/TM/7/2/2

NRC KFT. [2010]: Pálinkafogyasztás 2009-ben. Pálinkafogyasztási szokások, jellemzök és folyamatok a 18-49 éves magyar lakosság körében. Budapest.

OszKö BT. - TNS [2003]: Pálinka-marketingstratégia. Budapest.

R Core TeAm [2020]: R: A Language and Environment for Statistical Computing. R Foundation for Statistical Computing. Vienna. https://www.R-project.org/.

Rose, J. M. - Bliemer, M. C. J. [2009]: Constructing efficient stated choice experimental designs. Transport Reviews. Vol. 29. No. 5. pp. 587-617. https://doi.org/10.1080/ 01441640902827623

Szegedyné Fricz Á. - SzAKos D. - Bódi B. - KASZA Gy. [2017]: Pálinka: fogyasztói ismeretek, preferenciák, fogyasztási szokások, marketinglehetőségek. Gazdálkodás. 61. évf. 2. sz. 158-170. old. https://doi.org/10.22004/ag.econ.264586

TÖRÖK Á. [2013]: Hungarikumok - Magyarország földrajzi árujelzői. Doktori disszertáció. Budapesti Corvinus Egyetem. Budapest.

TÖRÖK, Á. - MARÓ, Z. M. [2020]: Profitability patterns in the Hungarian pálinka industry: The performance of the commercial distilleries. Georgikon for Agriculture. Vol. 24. No. 3. pp. 86-97.

TotTH G. - FodOR M. - HLÉDIK E. [2011b]: Fogyasztói vélemények és preferenciák a pálinka piacán. Élelmiszer, Táplálkozás és Marketing. 8. évf. 1-2. sz. 41-47. old.

TotTh G. - HLÉDIK E. - FODOR M. [2011a]: Pálinkával kapcsolatos fogyasztói percepciók és preferenciák elemzése kvalitatív kutatás eredményeinek tükrében. Marketing \& Menedzsment. 45. évf. 2. sz. 11-15. old.

Totth G. - KovÁcs I. - MezŐnÉ Oravecz T. É. - Zarándné VÁmosi K. [2017]: A fiatalok pálinkafogyasztási szokásai. In: Bányai E. - Lányi B. - Töröcsik M. (szerk.): Tükröződés, társtudományok, trendek, fogyasztás: Egyesület a Marketing Oktatásért és kutatásért (EMOK) XXIII. országos konferencia, Pécs, 2017. augusztus 28-30: Tanulmánykötet. Pécsi Tudományegyetem. Pécs.

TotTh G. - MeZÖNÉ Oravecz T. É. - ZARÁndnÉ VÁmosi K. [2018a]: A pálinkafogyasztás és a fogyasztói szokások változása. Prosperitas. 5. évf. 2. sz. 87-98. old. https://doi.org/ 10.31570/Prosp_2018_02_5

Totth G. - MezőnÉ Oravecz T. É. - ZarÁndnÉ VÁmosi K. [2018b]: A pálinka fogyasztási és vásárlási szokásainak kvalitatív vizsgálata. Prosperitas. 5. évf. 2. sz. 99-115. old. https://doi.org/10.31570/Prosp_2018_02_6 
Train, K. E. [2009]: Discrete Choice Methods with Simulation. Cambridge University Press. Cambridge.

VAN ITtersum, K. - CANDEL, M. - TORELLI, F. [1999]: The market for PDO/PGI protected regional products: Consumers' attitudes and behaviour. In: Sylvander, B. - Barjolle, D. Arfini, F. (eds.): The Socio-Economics of Origin Labelled Products: Spatial, Institutional and Coordination Aspects. Proceedings of the $67^{\text {th }}$ EAAE Seminar. Institut national de la recherche agronomique. Paris. pp. 210-221.

WÄGELI, S. - JANSSEN, M. - HAMM, U. [2016]: Organic consumers' preferences and willingness-topay for locally produced animal products. International Journal of Consumer Studies. Vol. 40. No. 3. pp. 357-367. https://doi.org/10.1111/ijcs.12262

WANG, J. - GE, J. - MA, Y. [2018]: Urban Chinese consumers' willingness to pay for pork with certified labels: A discrete choice experiment. Sustainability. Vol. 10. No. 3. p. 603. https://doi.org/10.3390/su10030603 